\title{
Impact of Socio-Economic Factors on Adoption of Farmers towards Cultivation of Medicinal Plants in Udaipur Division of Rajasthan State in India
}

\author{
M. Kanwat (Corresponding author) \\ ICAR RC for NEH Region AP Centre, Basar, Arunachal Pradesh, India \\ Tel: 91-7568-912-689_E-mail: kanwat_manish1980@yahoo.co.in \\ B.L. Meena \\ Krishi Vigyan Kendra, Rajsamand, MPUAT, Udaipur, Rajasthan, India \\ Tel: 91-9414-822-272Ｅ-mail: blmpuat@gmail.com \\ P. Suresh Kumar \\ Central Tuber Crops Research Institute, Trivandrum, Kerala, India \\ Tel: 91-8714-222-820 E-mail: psureshars@gmail.com
}

\section{Chargotra}

JAA, Department of Agriculture, Jammu and Kashmir, Jammu, India Tel: 91-9796-629-013Ｅ-mail: mchargotra@yahoo.com

A. Pareek

Deptt. of Entomology, RCA, Udaipur, Rajasthan, India

Tel: 91-9414-259-514Ｅ-mail: pareek.ento@gmail.com

R.K Meena

Directorate of Cashew Research, Puttur, DK, Karnataka, India

Tel: 91-9001-556-628Ｅ-mail: rkmeena8119@yahoo.com

Received: May 13, 2011

doi:10.5539/jas.v4n2p49
Accepted: May 27, $2011 \quad$ Online Published: December 21, 2011

URL: http://dx.doi.org/10.5539/jas.v4n2p49

\begin{abstract}
There has not been any major step for mass cultivation of medicinal plants in India. In this context, review of factors affecting the cultivation of medicinal plants is very important. This study has also been accomplished for the purpose of identification of socio-economic factors effective on the adoption of medicinal plants cultivation in the Udaipur division of Rajasthan, India. A survey was conducted using a stratified random sampling to collect data from farmers of selected rural in Udaipur and Chittorgarh region, Southern Rajasthan, India. The questionnaire validity and reliability were also determined to enhance the dependability of the result. The subjects under study were then divided into two groups of adopters and non-adopters. A total of 50 adopters and 40 non-adopters were studied for effective factors. Results showed that the most important socio-economic factors that influence on the adoption of medicinal plants cultivation in Udaipur division of province are age, number of farm patches, yearly income from agricultural activities and utilization system.
\end{abstract}

Keywords: Medicinal plants, Adoption, Udaipur, Socio-economic factors, Rajasthan, India 


\section{Introduction}

India is one of the richest floristic regions of the world and is well-known for its ancient heritage regarding medicinal plants and plants drugs. India has 16 agro-climatic zone, 45,000 different plants species, out of which 15,000 are medicinal. The Indian system of medicine has identified 1.500 medicinal plants, of which 500 species are mostly used in preparation of drugs. Presently, the forest area in the Indian desert is only $2.41 \%$ of the total geographical area extending from western Indo-Pak border to the dry deciduous mixed forest of the Aravalli hills and the Southern plateau (Tripathi and Arya, 2002). The first initiative to cultivate medicinal plants as an income-generating activity took place in India during the Second World War, when an acute scarcity of drugs led to the cultivation of a good number of species (Choi et al., 2001). In response to growing demand by the drug manufacturing industry and also to reduce pressure on species collected from the natural wilderness, various government and industry initiatives to produce medicinal plants through cultivation were developed in different parts of the world. Such initiatives were observed in China, India, Guatemala, South Africa and in some European countries(Schipmann et al., 2002). In India, a notable livelihood-focused venture was undertaken in which formal institutions successfully introduced medicinal plants into the traditional farming system to provide farmers with a regular income (Shukla and Sinclair, 2009). Along with many other stakeholders interested in linking medicinal plant production and income generation, the WWF (2002) argues that primary producers are likely to consider high yielding medicinal plants that are responsive to economies of scale, fast-growing, and demanding less space as economically attractive. Further, cultivation will be particularly advantageous for community members where there are long-standing partnerships and contractual arrangements to supply manufacturers. In this respect, Hamilton (2004) considers the cultivation of medicinal plants as attractive to relatively well-off people with better access to land, financial capital, and information. He holds the view that the virtually landless and other disadvantaged sectors of society would fail to benefit from such cultivation. Our study try to challenge Hamilton's view by examining whether cultivation and homestead growing of medicinal plants are gaining ground among the marginal farmers and households that own only a meagre piece of land under Indian condition.

The estimated area under the medicinal crops in India is around two lakh hectares. Presently commercial cultivation of medicinal plant in India is restricted to few crops like Plantago ovata (Isabgol), Trachyspermum copticum (Ajwain), Withania somnifera (Ashwaganda), Papaver somniferum(Opium poppy), Cassia angustifolia (Senna) etc. Nearly 75 per cent of the plant material used in indigenous medicines is collected from forests and wild habitats (Anonymous, 2000). India, Brazil and China are the largest exporters of medicinal plants. Trade of medicinal plants from India is estimated to be worth Rs.550 crore and likely to reach Rs.1,000 crores. The World Health Organization estimates the present demand for medicinal plants is about US \$14 trillion a year and projected demand by the year 2050 is US \$ 5 billion. Medicinal plants related trade in India is around has been put at over $\$ 60$ billion per year. India earned only 436 crores while China 22000 crores and Thiland 10000 crores respectively (Sen, 2004). Despite the vast potential for exploiting the market for medicinal, aromatic and exotic plants this sector is still in the nascent stage among many promising country. India's share of worlds markets is only 0.5 per cent which amount to 60-80 million rupees per year.

Rajasthan with geographical area of 342 lac sq $\mathrm{km}$ is the largest state of the country. The state is quite rich in diversity of medicinal plants. The herbs of are mostly found growing in the wild \& forms the base of various drugs used in different systems of medicine. Though number of medicinal plants are in cultivation in Rajasthan only few medicinal plants like Isabgol, Ashwagandha, Sonamukhi (Cassia anugustifolia) and commonly known as Sanaya and Mehandi (lawsonia alba) could get a sizeable area. Geographically the state of Rajasthan is distinguished into six divisions out of which Udaipur division is selected purposively. The characteristic feature of Udaipur division is that it is surrounded by Aravali hills, which is very rich in flora including medicinal plants. Ajwain and Isabgol are two important medicinal crops commonly grown in Udaipur division, particularly in Udaipur and Chittorgarh districts. In Rajasthan the medicinal plants are cultivated in area of 253745 ha with a total production of 142142 tonnes and average productivity of $560 \mathrm{~kg} / \mathrm{ha}$ (Anonymous, 2007). The total area of Isabgol in the state of Rajasthan is 136277 ha with a production of 49130 million tons. The area and production of Isabgol in Udaipur division is 2406 ha and 919 million tons respectively (Anonymous, 2006). Keeping this in view, a study was undertaken on to study the farmers' response towards the adoption of medicinal plants in Udaipur division of Rajasthan" to look into the respondents response and the relative economics of medicinal crop vis-a via traditional crop. Besides, find out the socio-economic factors associated with the adoption of cultivation of medicinal plants.

\section{Materials and Methods}

\subsection{Study Area}

The present study was conducted in Udaipur and Chittorgarh districts. Udaipur district lies between 
$28.3^{\circ} \mathrm{N}$ latitude and $75^{\circ} \mathrm{E}$ longitude at an elevation of 579.5 meters above mean sea level. Udaipur district divided into ten tehsils constituting eleven panchayat samities. The district consists of 498 Gram Panchayats with a total population of about 20,86,225 as per the census 2001. According to the latest estimates, total geographical area of Udaipur district is 19,13,696 hectares out of which about 5,20,622 hectares is cultivated. The climatic condition of this district is most suitable for cultivation of medicinal plants. Whereas, Chittorgarh district located in the southern part of the state of Rajasthan, in the northwestern part of India. It is located beside a high hill near the Gambheri River. Chittorgarh District is located between $23^{\circ} 32^{\prime}$ and $25^{\circ} 13^{\prime}$ north latitudes and between $74^{\circ} 12^{\prime}$ and $75^{\circ} 49^{\prime}$ east longitudes in the southeastern part of Rajasthan state. It divided into fourteen tehsils constituting 16 panchayat smaities with a total population of 20,37167 as per the census 2001. The district encompasses 10,856 square km (3.17 per cent of the Rajasthan State) area of land. The topography of the district is generally undulating with hills belonging to the Aravali Ranges scattering over the entire region. Four major rivers run through the district, namely Chambal, Banas, Bedach and Jakaharn along with tributaries such as Gambhiri, Barhmani and Gunjali. The programme on promotion of medicinal plants cultivation has been taken up by both Government and non-government organizations in the district.

\subsection{Data and Sampling Technique}

The data reported here were collected to identify socio-economic factors critical to adoption of medicinal plants cultivation. This study was carried out by survey during May and June 2008 in selected villages of Mavli Panchayat samities of Udaipur district and Nimbahera Panchayat Samities from Chitorgarh districts (Table 1) of Udaipur division province of Southern Rajasthan (Fig.1).

The sampled population in each village was stratified into two categories, medicinal growers-those who adopted and continue to practice medicinal plants cultivation and non-medicinal growers it means those who have never opted medicinal plants for cultivation. From each village list, a random sampling approach was used to select the respondents. This sampling technique was used to avoid conscious or unconscious bias in the selection of sampled households and ensured that the selected sample was representative of the population. According to Table 2 and with keeping 5\% error due to classified questions selected 90 farmers as sample size.

In total 90 farmers were selected of which $50(55.6 \%)$ were medicinal plants cultivation and $40(44.4 \%)$ non medicinal plant grower (Table 1). The instruments used for data collection was questionnaire with open and closed questions. The questionnaire was pre-tested by interviewing three farmers. After some modifications, it was tested again with 5 other respondents. The dependent variable was the adoption of medicinal plants cultivation among farmers of Chittorgarh and Udaipur province of Rajasthan.

The dependent variable was dichotomized with a value 1 if a farmer was an adopter of medicinal plants cultivation and 0 if non-adopter. Data analysis was conducted with software of Statistical Package for Social Sciences, 17 version (SPSS 17). Frequency, percent and standard deviation were used for the descriptive analysis of data. Chi-square test, t-test and Mann-Whitney test were used for inferential analysis data.

\subsection{Mann-Whitney Test (Inferential analysis data)}

The Mann-Whitney or U-test, is a statistical comparison of the mean. The U-test is a member of the bigger group of dependence tests. Dependence tests assume that the variables in the analysis can be split into independent and dependent variables. A dependence tests that compares the mean scores of an independent and a dependent variable assumes that differences in the mean score of the dependent variable are caused by the independent variable. In most analyses the independent variable is also called factor, because the factor splits the sample in two or more groups, also called factor steps. Other dependency tests that compare the mean scores of two or more groups are the F-test, ANOVA and the t-test family. Unlike the t-test and F-test, the Mann-Whitney U-test is a non-paracontinuous-level test. That means that the test does not assume any properties regarding the distribution of the underlying variables in the analysis. This makes the Mann-Whitney U-test the analysis to use when analyzing variables of ordinal scale. The Mann-Whitney U-test is also the mathematical basis for the H-test (also called Kruskal Wallis $\mathrm{H}$ ), which is basically nothing more than a series of pairwise U-tests.

The Mann-Whitney U-test is mathematically identical for conducting an independent sample t-test (also called 2-sample t-test) with ranked values. This approach is similar to the step from Pearson's bivariate correlation coefficient to Spearman's rho. The U-test, however, does apply a pooled ranking of all variables. Because the Mann-Whitney U-test is a non-paracontinuous-level test it does not require a special distribution of the dependent variable in the analysis. Thus it is the best test to compare mean scores when the dependent variable is not normally distributed and at least of ordinal scale. For the test of significance of the Mann-Whitney U-test it is assumed that with $n>80$ or each of the two samples at least $>30$ the distribution of the U-value from the 
sample approximates normal distribution. The U-value calculated with the sample can be compared against the normal distribution to calculate the confidence level.

The goal of the test is to test for differences of the media that are caused by the independent variable. Another interpretation of the test is to test if one sample stochastically dominates the other sample. The U-value represents the number of times observations in one sample precede observations in the other sample in the ranking. Which is that with the two samples $X$ and $Y$ the $\operatorname{Prob}(X>Y)>\operatorname{Prob}(Y>X)$. Sometimes it also can be found that the Mann-Whitney U-test tests whether the two samples are from the same population because they have the same distribution. Other non-paracontinuous-level tests to compare the mean score are the Kolmogorov-Smirnov Z-test, and the Wilcoxon sign test

\section{Results and Discussions}

\subsection{Descriptive analysis of data}

In this study, results of data on descriptive analysis in table 3 showed that majority 58.88 per cent of the respondents belongs from the medium level of age group (47yrs-69yrs) and 18.90 per cent of the respondents were belongs from the older category (above 69yrs) group of age. Among responders $36.7 \%$ illiterate, $23.3 \%$ primary-school level, $18.9 \%$ middle level education, $13.3 \%$ higher secondary education and only $7.8 \%$ have a graduation and diploma. A critical observation of table revealed that $52.22 \%$ of the respondents engaged in agriculture as a prime occupation and $28.90 \%$ of the farmers were committed in agriculture and allied sector as their occupation and $4.44 \%$ of the clientele engaged in service as their main occupation and agriculture being as secondary occupation.

Majority (48.90\%) of the respondents fell under the category of small farmers with having less than 2 ha of their land holding capacity and $41.10 \%$ of the farmers were under marginal category with less than 1 ha. of land holding and only $10 \%$ of the respondents were belonging as large farmers with more than 2 ha. of their land holding capacity. The data reveals that majority of the farmers were belongs from small and marginal category of farmers.

A critical analysis of the tables reveals that $51.10 \%$ of the respondents emanate to the medium income groups (Rs.41179.61- Rs. 77298.47) and only $13.36 \%$ of the respondents were earned more than Rs.77298.47/- annum from their land. Majority of the farmers $(64.44 \%)$ had passive social participation, while only 35.56 per cent farmers revealed high social participation. $47.80 \%$ of the respondents have less extension contacts and $40 \%$ of the respondents have medium level of extension contact, respectively.

\subsection{Inferential analysis of data}

In this study, results of Chi-square test in Table 4 showed that there was a significant relation between adoption of medicinal plants cultivation and variables of extension contact $\left(\mathrm{p}<0.05\right.$ and $\left.\chi^{2}=3.879\right)$, land holding capacity of the respondents $\left(\mathrm{p}<0.05\right.$ and $\left.\chi^{2}=8.319\right)$ and education level $(\mathrm{p}<0.05$ and $\chi=8.707)$. But there was no significant relation between adoption of medicinal plants cultivation and variables of age ( $p>0.05$ and $\left.\chi^{2}=2.102\right)$, occupation ( $>0.05$ and $\left.\chi^{2}=0.960\right)$, social participation $\left(p>0.05\right.$ and $\left.\chi^{2}=0.613\right)$ and annual income from agriculture and non-agricultural activities ( $p>0.05$ and $\left.\chi^{2}=4.525\right)$ respectively.

Results of t-test in Table 5 showed that there was a significant difference between the two groups of adopters and non-adopters of medicinal plants cultivation regarding variables of number of age $(\mathrm{p}<0.05$ and $\mathrm{t}=3.921)$ and education $(\mathrm{p}<0.05$ and $\mathrm{t}=2.351)$, annual income $(\mathrm{p}<0.05$ and $\mathrm{t}=3.012)$ respectively. But, there was no significant difference between the two groups of adopters and non-adopters regarding variables land holding capacity $(p>0.05$ and $t=1.707)$, occupation $(p>0.05$ and $t=0.308)$, extension contact $(p>0.05$ and $t=0.287)$ and social participation $(\mathrm{p}>0.05$ and $\mathrm{t}=0.192)$.

Mann-Whitney test in Table 6 demonstrated that there was a significant difference between the two groups of adopters and non-adopters of medicinal plants cultivation regarding variables of age status $(\mathrm{p}<0.05$ and $\mathrm{z}=$ $3.571)$, occupation $(p<0.01$ and $z=4.860)$,education $(p<0.05$ and $z=2.741)$ and annual income $(p<0.05$ and $z=3.078)$. But there was no significant difference between the two groups of adopters and non-adopters regarding variables of land holding capacity $(\mathrm{p}>0.05$ and $\mathrm{z}=1.577)$, extension contact $(\mathrm{p}>0.05$ and $\mathrm{z}=0.222)$ and social participation ( $p>0.05$ and $z=0.182)$ respectively. Referring to the results of this study, effect of age on their adoption, education level of the respondents, occupation of the respondents and annual income received from agricultural activities and utilization system on adoption almost have the same direction toward the results of many other researchers wherein the adoption of innovations and different technologies in agriculture namely some researchers outcome like Saka et al. (2005), Tabaraee and Hassanne jad (2009) and Rostami et al. (2008). It is inferred that such traits could be among limitative factors on adoption of medicinal plants culture across the 
non-adopters. Besides the results of current study unto the variables age, education level, amount of land ownership (per hectare), number of visit refer to agricultural services during a year, membership in social institutions were commonly unlike some researchers outcomes Tabaraee and Hassannejad (2009), Faraji and Mirdamadi (2006), Kapanda et al. (2005), Joshi and Pandy (2005), Saka et al. (2005), and Rezvanfar and Mandape (2000). As noticed in multiple researches, most of these traits are reported effectively on the adoption of technologies and various innovations but lack of meaning of these traits in this study signifies that there is no major difference among the groups of adopters and non- adopters in studied region. For this reason, there won't be major restriction in order to adopt medicinal plants culture among the non-adopters of this technology in comparison with the adopters.

\section{Conclusions and Recommendation}

In general, the results of survey indicate that the most important socio-economic factors that influence on the adoption of medicinal plants culture in Udaipur division of Rajasthan province are age, education, occupation and annual income received from agricultural activities. Non- adopters difference in comparison with the adopters of medicinal plants culture in Udaipur division of Rajasthan depends on such these traits and generally is trivial. At present increasing attention is given to the stimulation of medicinal plant cultivation as a means to combine biodiversity conservation and poverty alleviation. Considering the role of medicinal plant cultivation in contributing to increased income and employment of poor people, the study has been ongoing for a too limited period to present clear results on income effects. It is essential to give careful attention to the selection of specific target groups and assessment of their livelihood conditions, and to identify how cultivation practices can be adjusted to these livelihood conditions. In our project perhaps the selection of the target group was not optimal. The women hawkers spend most of their time at the market rather than at home, and thus cultivation competes with their trading activities. Moreover, in contrast to initial assumptions, they were not all collecting the traded medicinal plants themselves.

It is suggested to promote more effective medicinal plants culture as regards, three meaningful variables of four shows the economical difference between two groups of the adopters and non-adopters of medicinal plants culture in studied region. It should provide financial resources, facilities and necessary materials so as to develop medicinal plants and make it more valuable. Finally, plenty of medicinal plants of the studied region are grown wildly; it is suggested to study more on domestication of these plants and determining the profitable cultural features in order to specify the requirements of planting, maintenance and harvesting of these plants. There is hope that the strength of Udaipur region farmers' economy will be improved by utilization of medicinal plants cultivated in specific farms.

\section{References}

Anonymous. (2000). Report of the Task Force on Conservation and Sustainable Use of Medicinal Plants, Planning Commission, Govt of India, New Delhi.

Anonymous. (2007). Rajasthan Agricultural Statistics: At a Glance (Statistics), Department of Agriculture, Jaipur, Rajasthan.

Anonymous. (2006). Rajasthan Horticulture Statistics, Directorate of Horticulture, Pant Krishi Bhawan, Jaipur. Rajasthan.

Choi, J. L., Choi, J.C., Choi, J.W. \& Choi, J.C. (2001). The analysis of association members consciousness inclination for development of forestry association. Journal of Forest Resource Kangwan National University, $17: 47-61$.

Faraji, E., \& Mirdamadi, S.M. (2006). Assessing the role of extension in adoption of the insurance by apple producers in the Damavand area. Journal of Agricultural Science, 12(3): 489-500.

Hamilton, A.C. (2004). Medicinal Plants Conservation and Livelihoods. Biodiversity and Conservation. Vol 13. Kluwer Academic Publishers. The Netherlands, pp 1477-1517.

Joshi, G., \& Pandy, S. (2005). Effects of farmers' perception on the adoption of modern rice varieties in Nepal. Conference on International Agricultural Research for Development. Stuttgart-Hohenheim, 11-13 October 2005.

Kapanda, K., Matiya, G., N'gong'ola, D.H., Jamu, D., \& Kaunda Ek. (2005). A logit analysis of factors affecting adoption of fish farming in Malawi: a case study of Mchinji Rural Development Program. Journal of Applied Science, 5(8): 1514-1517. 
Rezvanfar, A., \& Mandape, M.K. (2000). Adoption behaviour of livestock owners in east Azarbayjan province of Iran. Quarterly Journal of Agricultural Economic Studies, 82 (30):201-218. (In Farsi).

Rostami, F., Shaaban Ali Fami, H., Movahed Mohammadi, H., \& Iravani, H. (2008). Factors affecting on the adoption toward insurance (case study: Harsin county in Kermanshah province) Quarterly Journal of Agricultural Economic Studies, 15 (60): 1-21. (In Persian).

Saka, J.O., Okoruwa, V.O., Lawal, B.O., \& Ajijola, S. (2005). Adoption of improved rice varieties among small-holder farmers in south-western Nigeri. World Journal of Agricultural Science, 1(1): 42-49.

Schippmann, U., Leaman, D.J. \& Cunningham, A.B. (2002). Impact of cultivation and gathering of medicinal plants on biodiversity: Global trends and issues. Biodiversity and the Ecosystem Approach in Agriculture. Proc. 9th session of the Commission on Genetic Resources for Food and Agriculture. Oct. 12-13, 2002. FAO, Rome. http://fao.org/docrep/fao/005/aa010e/AA010E00.pdf

Sen, N.L. (2004). Importance and scope of medicinal and aromatic plants. Winter school on "Commercial Exploitation of Underutilized Medicinal and Aromatic Plants" held at Rajasthan college of Agriculture , Udaipur, Rajasthan. Winter school compendium ( $1^{\text {st }}-21^{\text {st }}$ October $)$ Pp-1-6.

Shukla, S., \& Sinclair, A. J. (2009). Becoming a traditional medicinal plant healer: Divergent views of practicing and young healers on traditional medicinal plant knowledge skills in India. Ethnobotnical Research Application, 7: 39- 51.

Tabaraee, M., Hassannejad, M. (2009). Factors affecting the acceptance of agricultural extension programs with regards to process of agricultural development Case study: Wheat farmers in Mashhad. Journal of Economics and Agricultural Development, 23(1): 59-68.

Tripathi, Y.C., \& Arya, R. (2002). Floral Resources of Indian Thar Desert. In Biorespirces Technology, CBS Publishers and Distributors, New Delhi, pp.16-33.

World Wildlife Fund (WWF). (2002). Cultivation versus wild harvesting of medicinal plants: Is cultivation the sole solution? WWF Fact Sheet-2: August. WWF, Cambridge, UK.

Table 1. Village-wise selected respondents

$\mathrm{N}=90$

\begin{tabular}{|c|c|c|c|c|c|}
\hline \multirow[t]{2}{*}{ District } & \multirow{2}{*}{$\begin{array}{c}\text { Panchayat } \\
\text { Samities }\end{array}$} & \multirow[t]{2}{*}{ Village } & \multicolumn{3}{|c|}{ Selected respondents } \\
\hline & & & Small & Marginal & Total \\
\hline \multirow[t]{5}{*}{ A. Udaipur } & \multirow[t]{5}{*}{ 1) Mavli } & a) Sangwa & 4 & 5 & 9 \\
\hline & & b) Junavas & 4 & 5 & 9 \\
\hline & & c) Asaja & 4 & 5 & 9 \\
\hline & & d) Shayam ki badi & 4 & 5 & 9 \\
\hline & & e) Intalye & 4 & 5 & 9 \\
\hline \multirow[t]{5}{*}{ B. Chittorgarh } & \multirow[t]{5}{*}{ 1) Nimbahera } & a) Godula & 4 & 5 & 9 \\
\hline & & b) Charliya & 4 & 5 & 9 \\
\hline & & c) Mangrol & 4 & 5 & 9 \\
\hline & & d) Keli & 4 & 5 & 9 \\
\hline & & e) Tai & 4 & 5 & 9 \\
\hline 2 & 2 & 8 & 40 & 50 & 90 \\
\hline
\end{tabular}

Table 2. Total Sample size used in the study area

\begin{tabular}{|c|c|c|}
\hline Sample size & f & \% \\
\hline Medicinal growers & 50 & 55.60 \\
\hline Non medicinal growers & 40 & 44.40 \\
\hline Total & 90 & 100.00 \\
\hline
\end{tabular}

$\mathrm{f}=$ Frequency,

$\%$ per cent 
Table 3. Frequency, percent, mean and standard deviation of socio-economic characteristics of farmers

\begin{tabular}{|c|c|c|c|c|c|c|}
\hline SL.No & Characteristics & Category & $\mathbf{f}$ & $\%$ & Mean & SD \\
\hline \multirow[t]{3}{*}{1} & \multirow[t]{3}{*}{ Age } & Young (below 46 years) & 20 & 22.22 & \multirow[t]{3}{*}{57.54} & \multirow[t]{3}{*}{11.54} \\
\hline & & Medium (between 47-69years) & 53 & 58.88 & & \\
\hline & & Older (above 69 years) & 17 & 18.90 & & \\
\hline \multirow[t]{5}{*}{2} & \multirow[t]{5}{*}{ Education level } & Illiterate & 33 & 36.70 & & \\
\hline & & Primary education & 21 & 23.30 & & \\
\hline & & Middle school & 17 & 18.90 & & \\
\hline & & Higher secondary & 12 & 13.30 & & \\
\hline & & Graduation & 07 & 7.80 & & \\
\hline \multirow[t]{3}{*}{3} & \multirow[t]{3}{*}{ Land Holding } & Less than 1.0 ha. & 37 & 41.10 & 2.25 & 2.04 \\
\hline & & Upto 1 ha.to 2 ha. & 44 & 48.90 & & \\
\hline & & More than 2 ha. & 09 & 10.00 & & \\
\hline \multirow[t]{4}{*}{4} & \multirow[t]{4}{*}{ Occupation } & Landless labour & 13 & 14.44 & & \\
\hline & & Agriculture & 47 & 52.22 & & \\
\hline & & Agriculture+ allied & 26 & 28.90 & & \\
\hline & & Agriculture + service & 04 & 4.44 & & \\
\hline \multirow[t]{3}{*}{5} & \multirow[t]{3}{*}{ Annual Income } & $<41179.61$ & 32 & 35.60 & 59239.04 & 18059.43 \\
\hline & & Upto 41179.61 to 77298.47 & 46 & 51.10 & & \\
\hline & & $>77298.47$ & 12 & 13.30 & & \\
\hline 6 & Extension contact & Low extension contact (No contact/month) & 43 & 47.80 & 1.90 & 0.73 \\
\hline & & Medium extension contact (1-2 times/month) & 36 & 40.00 & & \\
\hline & & High extension contact ( $>2$ times/month) & 11 & 12.20 & & \\
\hline 7 & Social Participation & Active Participation & 32 & 35.55 & 2.50 & 1.43 \\
\hline & & Passive participation & 58 & 64.44 & & \\
\hline $\mathrm{f}=$ freque & ncy, $\%$ per cent & & $\mathrm{S}$ & rvey res & lts, 2010- & \\
\hline $\begin{array}{l}\text { Table } 4 . \\
\text { Chi-squar }\end{array}$ & $\begin{array}{l}\text { The effect of soci } \\
\text { e test }\end{array}$ & onomic & & & & \\
\hline & lependent variable & Adoption & & & $\mathbf{P}$ & \\
\hline & Age & $2.102^{\mathrm{Ns}}$ & & & 0.315 & \\
\hline & Education & $8.707^{*}$ & & & 0.013 & \\
\hline & ad Holding capacity & $8.319 *$ & & & 0.040 & \\
\hline & Occupation & $0.960^{\mathrm{Ns}}$ & & & 0.619 & \\
\hline & Annual Income & $4.525^{\mathrm{NS}}$ & & & 0.066 & \\
\hline & Extension Contact & $3.879^{*}$ & & & 0.049 & \\
\hline & ocial Participation & 0.613 & & & 0.434 & \\
\hline
\end{tabular}

NS: Non Significant, Significant at .05 per cent level of significance (Survey 2010-2011)

Table 5. Comparison of some socio-economic characteristics of adopter and non-adopter of medicinal plants cultivation using independent " $t$ "-test

\begin{tabular}{|c|c|c|c|c|c|c|c|}
\hline 5 & Group & $\mathbf{N}$ & Mean & SD & SEM & ' $t$ ' & Sig \\
\hline \multirow[t]{2}{*}{ Age } & Adopters & 50 & 49.90 & 12.45 & 1.76 & \multirow[t]{2}{*}{$3.921^{*}$} & \multirow[t]{2}{*}{0.000} \\
\hline & Non-Adopters & 40 & 58.77 & 7.87 & 1.24 & & \\
\hline \multirow[t]{2}{*}{ Education } & Adopters & 50 & 2.12 & 1.52 & 0.215 & \multirow[t]{2}{*}{$2.351^{*}$} & \multirow[t]{2}{*}{0.021} \\
\hline & Non-Adopters & 40 & 2.87 & 1.50 & 0.238 & & \\
\hline \multirow[t]{2}{*}{ Land Holding capacity } & Adopters & 50 & 1.77 & 0.548 & 0.077 & \multirow[t]{2}{*}{$1.707^{\mathrm{NS}}$} & \multirow[t]{2}{*}{0.091} \\
\hline & Non-Adopters & 40 & 1.99 & 0.662 & 0.100 & & \\
\hline \multirow[t]{2}{*}{ Occupation } & Adopters & 50 & 3.14 & 0.969 & 0.137 & \multirow[t]{2}{*}{$0.308^{\mathrm{NS}}$} & \multirow[t]{2}{*}{0.759} \\
\hline & Non-Adopters & 40 & 3.20 & 0.853 & 0.134 & & \\
\hline \multirow[t]{2}{*}{ Annual Income } & Adopters & 50 & 71189.44 & 16294.82 & 2304.43 & \multirow[t]{2}{*}{$3.012 *$} & \multirow[t]{2}{*}{0.003} \\
\hline & Non-Adopters & 40 & 60179.50 & 18334.72 & 2898.97 & & \\
\hline \multirow[t]{2}{*}{ Extension Contact } & Adopters & 50 & 1.88 & 0.872 & 0.123 & \multirow[t]{2}{*}{$0.287^{\mathrm{NS}}$} & \multirow[t]{2}{*}{0.775} \\
\hline & Non-Adopters & 40 & 1.92 & 0.525 & 0.083 & & \\
\hline \multirow[t]{2}{*}{ Social Participation } & Adopters & 50 & 2.64 & 1.49 & 0.211 & \multirow[t]{2}{*}{$0.192^{\mathrm{NS}}$} & \multirow[t]{2}{*}{0.849} \\
\hline & Non-Adopters & 40 & 2.70 & 1.45 & 0.220 & & \\
\hline
\end{tabular}

NS: Non Significant, Significant at .05 per cent level of significance (Survey 2010-2011)

$\mathrm{SEM}=$ Standard Error of Mean, $\mathrm{SD}=$ Standard Deviation 
Table 6. Comparison of some cultural characteristics of adopter and non-adopter of medicinal plants cultivation using Mann-Whitney test

\begin{tabular}{|c|c|c|c|c|c|c|}
\hline Characteristics & Group & $\mathrm{N}$ & Mean Rank & Sum of ranks & $\mathrm{Z}$ & Sig \\
\hline \multirow[t]{2}{*}{ Age } & Adopters & 50 & 36.71 & 1835.50 & \multirow[t]{2}{*}{$3.571^{*}$} & \multirow[t]{2}{*}{0.000} \\
\hline & Non-Adopters & 40 & 56.49 & 2259.50 & & \\
\hline \multirow[t]{2}{*}{ Education } & Adopters & 50 & 38.91 & 1945.50 & \multirow[t]{2}{*}{$2.741^{*}$} & \multirow[t]{2}{*}{0.006} \\
\hline & Non-Adopters & 40 & 53.74 & 2149.50 & & \\
\hline \multirow[t]{2}{*}{ Land Holding capacity } & Adopters & 50 & 41.73 & 2086.50 & \multirow[t]{2}{*}{1.577} & \multirow[t]{2}{*}{0.115} \\
\hline & Non-Adopters & 40 & 50.21 & 2008.50 & & \\
\hline \multirow[t]{2}{*}{ Occupation } & Adopters & 50 & 57.07 & 2853.50 & \multirow[t]{2}{*}{$4.860^{*}$} & \multirow[t]{2}{*}{0.000} \\
\hline & Non-Adopters & 40 & 31.04 & 1241.50 & & \\
\hline \multirow[t]{2}{*}{ Annual Income } & Adopters & 50 & 53.08 & 2654.00 & \multirow[t]{2}{*}{$3.078^{*}$} & \multirow[t]{2}{*}{0.002} \\
\hline & Non-Adopters & 40 & 36.03 & 1441.00 & & \\
\hline \multirow[t]{2}{*}{ Extension Contact } & Adopters & 50 & 45.00 & 2250.00 & \multirow[t]{2}{*}{0.222} & \multirow[t]{2}{*}{0.824} \\
\hline & Non-Adopters & 40 & 46.13 & 1845.00 & & \\
\hline \multirow[t]{2}{*}{ Social Participation } & Adopters & 50 & 45.06 & 2253.00 & \multirow[t]{2}{*}{0.182} & \multirow[t]{2}{*}{0.856} \\
\hline & Non-Adopters & 40 & 46.05 & 1842.00 & & \\
\hline
\end{tabular}

NS: Non Significant, Significant at .05 per cent level of significance (Survey 2010-2011)

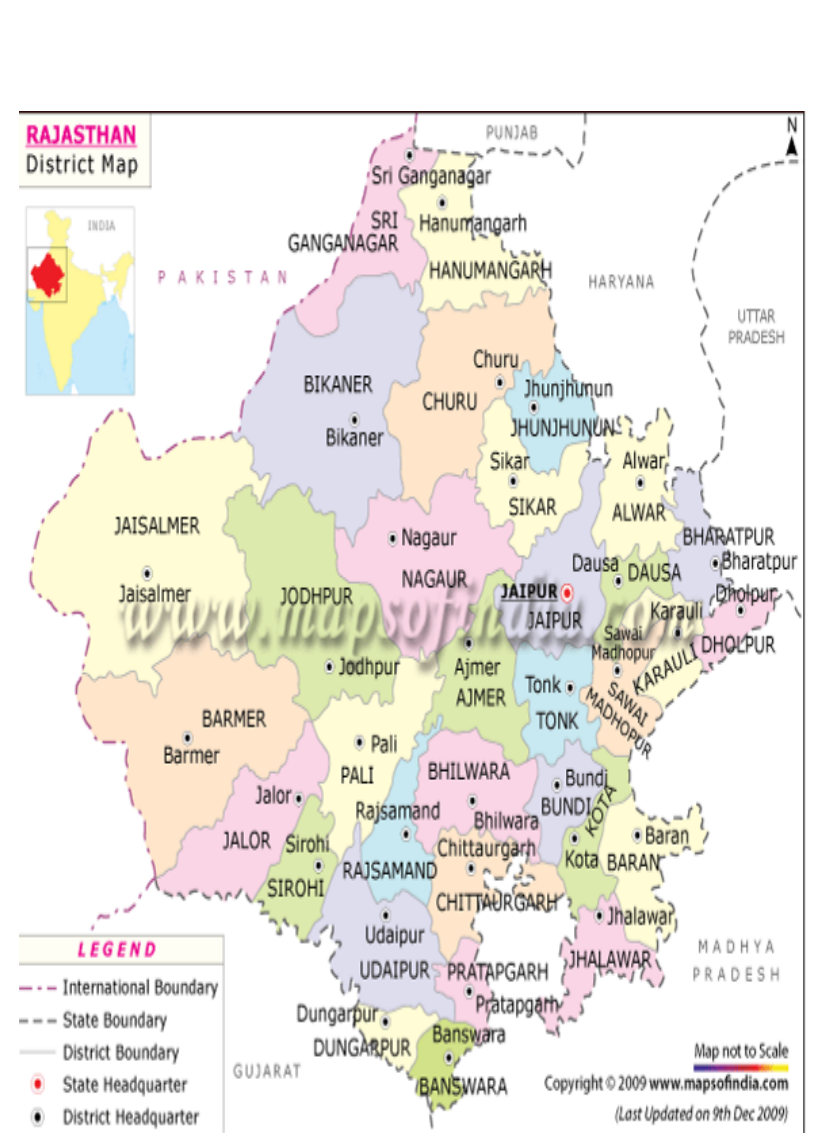

\section{RAJASTHAN}

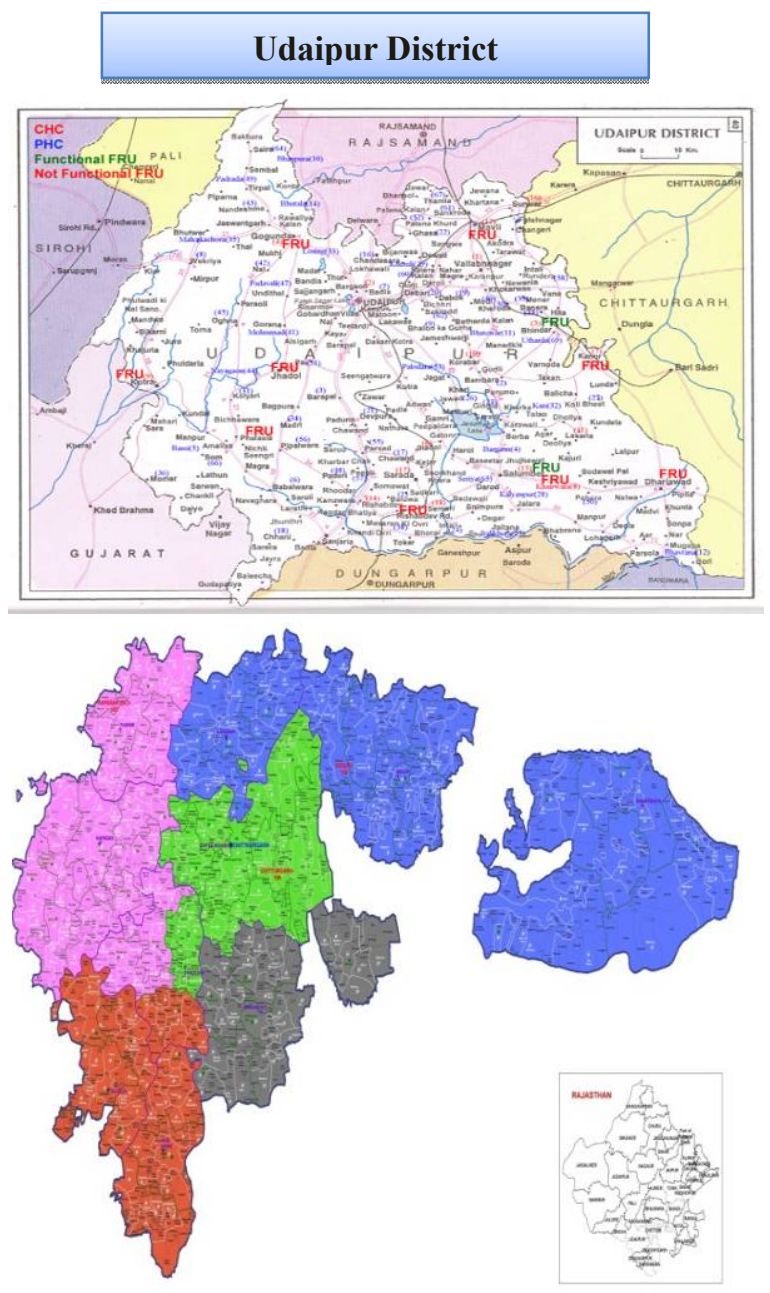

Chittorgarh District

Figure 1. Udaipur Division (Udaipur and Chittorgarh region) 